\title{
Towards an Analytical Framework of Science Communication Models
}

\author{
Brian Trench
}

\begin{abstract}
This chapter reviews the discussion in science communication circles of models for public communication of science and technology (PCST). It questions the claim that there has been a large-scale shift from a 'deficit model' of communication to a 'dialogue model', and it demonstrates the survival of the deficit model along with the ambiguities of that model. Similar discussions in related fields of communication, including the critique of dialogue, are briefly sketched. Outlining the complex circumstances governing approaches to PCST, the author argues that communications models often perceived to be opposed can, in fact, coexist when the choices are made explicit. To aid this process, the author proposes an analytical framework of communication models based on deficit, dialogue and participation, including variations on each.
\end{abstract}

Science communication has been telling a story of its own development, repeatedly and almost uniformly, for almost a decade. The story is a straightforward one: science communication used to be conducted according to a 'deficit model', as one-way communication from experts with knowledge to publics without it; it is now carried out on a 'dialogue model' that engages publics in two-way communication and draws on their own information and experiences.

This chapter examines the validity of the claim that we have been living through such a fundamental shift in approach, and considers the possibility that several models, including deficit and dialogue models, can coexist. I argue the need for clearer articulation of the choices being made in science communication practice and propose a framework for the structuring of those choices.

\section{From Deficit to Dialogue: a Story Too Often Told?}

The 'grand narrative' in public communication of science and technology (PCST) since the late 1990s has had compelling force. It has been replayed in policy statements, in academic studies, in debates on public communication within scientific communities, and in public debates on science-society relations. We have learned, the story goes, that one-way, top-down communication of packaged scientific information does not work. Now science communication makes it easier for the public to talk back, and scientists need to listen, so that understandings can be developed together.

One of the several remarkable features of this story is how broadly it has been adopted, across the continents and by governments, scientific societies, intergovernmental bodies, civil society organizations and many other interests. To give any one illustration would risk misrepresenting the universality of the process by which a key idea has diffused across the world and been naturalized.

There are, of course, local and specific variations, for example in the naming of some strategies as 'public engagement', but the main thrust of the argument is clear and it is shared: the old, 
traditional ways are discredited; the new ways are better. The story is not just one of opposition - it is one of evolution, of progress from deficit to dialogue.

After several years of repetition, the story may be wearing thin, at least as an accurate descriptive account of what has happened. It is, at best, implausible that scientific communities and those working closely with them in policy or publicity have shifted their approach radically over a short period. Cultural change, even at the level of relatively self-contained subcultures, tends to happen on longer cycles and to be more ambivalent. When the story is told in its British version, as one of change marked by a report from the House of Lords Select Committee on Science and Technology Committee (SCST 2000), the change of direction is all too neatly tied to the change of millennium. In fact, that report spoke, among other things, of a 'mood for dialogue' that was growing within the population over a longer time and might, therefore, take time to manifest itself more clearly.

In some scientific communities, too, the 'mood for dialogue' was evident several years before the House of Lords report. In the 1990s, the Biotechnology and Biological Sciences Research Council (BBSRC) in Britain stated that it had devised 'a programme of activities designed to enhance public access to science and scientists with a view to improving public confidence and stimulating open debate about science and technology, ${ }^{,}$. The council said its activities were increasingly about 'mutuality' and 'transparency in the way BBSRC interacts with die public'. Thus, the keywords of the dialogue model were established in at least one important field before this model received broader and higher level endorsement.

So, at the level of description, the deficit-to-dialogue story needs qualification. Indeed, it needs more, because in precisely that field of biotechnology and biological sciences there were particular pressures to open dialogue and the responses were equivocal. The widespread and sometimes militant social reaction to developments in biotechnology, and in genetic engineering in particular, could not be faced down by mere repetition of scientific information. A former New Scientist editor has recalled several initiatives from the late 1980s onwards to engage media and the wider public in discussion of the implications of then current scientific developments. He cites the example of the UK National Consensus Conference on Plant Biotechnology in 1994, sponsored by the BBSRC, but concludes that it was a 'one-off'. "No one at the top of the BBSRC saw the need to develop the model" (Dixon 2007).

In Ireland, the strong reaction from citizen groups to trials of genetically modified (GM) crops prompted scientists and companies in biotechnology and genetics to facilitate and engage in public debate, including with committed opponents of GM foods. A technology foresight report that contributed significantly to a radical increase in government spending on scientific research included among its recommendations a proposal for a 'national conversation on biotechnology' and advocated a communications strategy in biotechnology that uses a partnership approach with ongoing, transparent and open dialogue' (Technology Foresight Ireland 1999). As the heat went out of the GM foods debate, this recommendation disappeared from view. In 2004, a website established by government specifically to facilitate public education and debate on biotechnology was closed down.

We shall return later to consider the social and political factors that influence the adoption or abandonment of a science communication model. For now, we can further question the story of a uniform shift from deficit to dialogue by pointing to the very evident persistence of the deficit model. Sociologist Brian Wynne, who is strongly associated with the early identification and critique of the deficit model in the early 1990s (Wynne 1991. see also Ziman 1991), has observed the 'multifold reinventions of the public deficit model' (Wynne 2006). He and colleagues have noted that the apparent consensus about dialogue covers 'deeper ambivalence. 
Old assumptions continually reassert themselves ... No sooner have "deficit" models of the public been discarded than they reappear' (Wilsdon et al. 2005).

Perhaps the most visible example of an unreconstructed deficit model is the work of popular science writer Richard Dawkins. His is more than an individual case, as his book, The god delusion, has been a best-seller and clearly has wide resonance in scientific and scienceattentive communities and beyond. Through his books, lectures, TV programmes and many other public interventions, Dawkins presents a view of science and its place in the world that resonates widely within and beyond the scientific communities. Although a professor of public understanding of science at Oxford University, Dawkins has rarely reflected on the diversity of publics for science, and even less on the diversity of possible approaches to communication with those publics (Dawkins 2006).

He has increasingly narrowed his field of attention to a critique of religion and the obstacles he sees it presenting to the spread of science and reason in society. Two websites are maintained as a 'clear-thinking oasis' with Dawkins's support ${ }^{\mathrm{ii}}$. Dawkins calls on other clear thinkers to join his campaign:

The enlightenment is under threat. So is reason. So is truth. So is science, especially in the schools of America. I am one of those scientists who feels that it is no longer enough just to get on and do science. We have to devote a significant proportion of our time and resources to defending it from deliberate attack from organized ignorance. We even have to go out on the attack ourselves, for the sake of reason and sanity. (Richard Dawkins Foundation for Reason and Science 2007)

Dawkins's crusade links at least as much to the advocacy work of atheists, rationalists and sceptics as to any specifically science-based communities or movements. But the adoption of science's cause by such interest groups has perceptible influence among scientists, both as individual citizens and as professionals. Scientists and medical practitioners are well represented in such organizations. The 13th European Skeptics Conference met in 2007 in Dublin under the banner, 'The assault on science: Constructing a response'. The conference theme referred to the continuing rise in popularity of the complementary and alternative medicine sector, the ongoing battles between evolutionary biologists and the intelligent design movement, the increased activities of fundamentalist religious movements, the granting of degrees in science to students of alternative practices such as homeopathy and so on' iii

Other such initiatives cite postmodernist trends in contemporary culture and corporate special interests as further sources of antagonism to science. Sense About Science, a British group with many leading scientists among its supporters, is dedicated to 'work with scientists to respond to inaccuracies in public claims about science, medicine, and technology'. ${ }^{\text {iv }}$ The priority attached to this enterprise encourages a form of public communication that is inevitably didactic rather than dialogical.

The Sense About Science annual lecture in 2007 was delivered by medical scientist Professor Raymond Tallis, who identified the uncongenial climate for science:

... in ever more oppressive regulatory constraints, in opposition to ethical research on humans and animals and on responsible stem cell research, and in the credence given to anti-science, junk science, and to the authority of individuals who have no scientific training or understanding to pronounce on science.

Even where the vocabulary has changed, the underlying assumptions may be those that inform the deficit model. Wynne (2006) writes that public engagement with science activities is 'based, albeit ambiguously on closer inspection, on replacing the previous deficit model's primitive one-way assumption about educating an ignorant public into "(scientifically) proper attitudes" 
with an alternative two-way dialogue'. He concludes that the replacement is more nominal than real.

A review of the discussion of public communication in the publications of professional societies suggests that a deficit model remains the default option in many sectors of science (Trench and Junker 2001); it has its adherents among PCST practitioners and analysts, too (Trench 2007).

Given the persistence of the deficit model, it seems like an act of denial to state in a review of approaches and definitions that 'science communication as defined here cannot be considered as a one-way dissemination of information to the lay public' (Burns et al. 2003). That review proposes dialogue as a means to 'more effective science communication'; that is, to achieve certain ends decided at the point of origin. This suggests that the shift to two-way communication is partial.

Several models of science communication, including one-way dissemination, and the particular deficit-model application of one-way dissemination, continue to coexist with two-way models that place varying emphasis on interactivity. So, while the story being told in PCST circles undoubtedly has value as a reminder about the limits of one approach and the possibilities of another, it is more normative than descriptive. The supposed shift from deficit to dialogue has not been comprehensive; nor is it irreversible.

\section{Communication Models in Other Fields}

The discussion about models of science communication links to discussions in many other fields in which similar problems have been posed. It is perhaps inevitable that a relatively new field of inquiry and practice, such as science communication, needs to rerun such debates for itself. But this discipline is maturing and, in the spirit of listening and engagement espoused so widely in science communication, this section will refer to theoretical and strategic debates elsewhere in communication that have a bearing on PCST.

In communication theory, critiques of received transmission models from the 1970 had already focused on dialogue and conversation as defining activities, mainly because of the influence of German cultural critic Theodor Adorno and German social theorist Jurgen Habermas. A concept of two-way communication as dialogue came to form the centrepiece of a social and political theory espoused by British sociologist Anthony Giddens. He developed the concept of a 'dialogical democracy' as a more fully realized form of democracy and of dialogue as 'the capability to create active trust through an appreciation of the integrity of the other' (Giddens 1994).

The critique of mass media as one-way only had been prefigured in the late 1920s by the German playwright Bertolt Brecht, who contrasted 'distribution' and 'communication' in a frequently cited and insightful commentary on radio:

Radio should be converted from a distribution system to a communication system. Radio could be the most wonderful public communication system imaginable, a gigantic system of channels - could be, that is, if it were capable not only of transmitting but of receiving, of making the listener not only hear but also speak, not of isolating him but of connecting him. (Brecht 1979/80)

Adorno's critique of the cultural industries and Habermas's theory of the public sphere gave new life to the argument as it applied to media in general and to television in particular. Communication as a two-way process became the byword of much theorizing of media, society and culture. Mass media were widely seen to have contributed to the loss of conversation. 
The shift in thinking in mass communication theory and research challenged received ideas of the audience. Reviewing the future of the audience concept, communication theorist Denis McQuail noted that in the early days of communication research the audience was conceptualized as the body of 'receivers of messages at the end of a linear process of information transmission'. But this view gave way gradually to one of the media receiver 'as more or less active, resistant to influence, and guided by his or her own concerns, depending on the particular social and cultural context. The communication process itself has been reconceptualized as essentially consultative, interactive, and transactional' (McQuail 1997).

As digital and online media assumed a much larger place in the mass communication field, the notion of audience has come under greater strain, often giving way to the notion of 'users', which is drawn from information and communication technologies. Concepts of interactivity have been extensively debated, not only as they refer to human-computer interaction, but also as they refer to mediated communication processes between individuals and groups.

In journalism studies, the late James Carey, one of the most influential academics in the field, posited a possible "journalism of conversation' in the 1980s. The notion influenced a movement, known as 'public journalism' that problematized the presumed public that journalists addressed and proposed, as Carey put it, a more 'humble journalism' as a means to support more active engagement of citizens and politics (Rosen 1999). Rosen had to acknowledge that in the years ahead, there may be no people calling themselves public journalists' but, by the late 1990s, the underlying ideas were finding new vehicles and new forms of expression in the debates about citizen journalism on the web, and about the shifting boundaries of journalism.

Similar trends are visible in fields of communication more directly related to PCST, such as risk communication and health communication. To the received view of risk assessment, based on objective' calculations of probability and impact Sandman (1987) added the imaginatively named 'outrage' to account for 'subjective' factors. 'Call the death rate (what the experts mean by risk) "hazard". Call all the other factors, collectively, "outrage". Risk, then, is the sum of hazard and outrage. The public pays too little attention to hazard; the experts pay absolutely no attention to outrage. Not surprisingly, they rank risks differently. Risk perception scholars have identified more than 20 "outrage factors". These factors include voluntariness, control, and fairness. The resulting formulation, risk = hazard + outrage, is now widely used.

In health communication, a 'medical model' based on transmission of expert knowledge has been contrasted with an 'educational model' that takes account of the perceptions and understandings of the sectors of the population being addressed. But, reflecting the resilience of expert-centred approaches, Lee and Garvin (2003) criticize 'commonly accepted views of health communication [as] inadequate because they imply a one-way transfer of information based on a one-sided relationship between communicator and receiver'. They present three health communication practices that, they say, all "ignore the social context of information receivers, and ... deny the agency and adaptive powers of recipients". The authors propose that 'researchers and practitioners must move beyond traditional practices of information transfer (based on a "monologue") toward a more useful and appropriate concept of information exchange (based on a "dialogue")'. In a concluding observation that has resonance for science communication, they write: 'This change in orientation cannot possibly happen overnight, nor will it come without considerable changes in the relations of power embedded in the world of medicine'.

Even public relations - perhaps widely perceived as the branch of communications most strongly wedded to persuasion, even manipulation - was influenced by this spirit. From the 1980s, textbooks on public relations (such as Grunig and Hunt 1984) have contrasted one-way 
public information and publicity models with two-way models, whether 'asymmetrical' (that is, aimed to persuade more effectively through gathering information on publics) or symmetrical'. Symmetrical communication, in this context, refers to promotion of mutual understanding, exchange of information and negotiation of mutually beneficial solutions.

Beyond disciplines and activities defined as 'communication', for example in science education, there is also increasing emphasis on the need to engage the relevant 'audiences' or 'publics' (in science education, students) more actively. Approaches characterized as 'inquirybased', 'interactive' or 'project-based' draw on a longer established educational philosophy of constructivism that stresses the understandings and experiences that students bring. Nobel Prize-winning physicist Carl Wieman is a high-profile exponent of such an approach, leading an initiative at the University of British Columbia in Canada to transform science teaching so that students 'reason through ideas and argue their points of view' (Cartlidge 2007).

Inevitably, the trend in communication theory has had its critics. John Durham Peters noted that 'dialogue has attained something of a holy status' with contemporary dialogians (a term he chose to rhyme with theologians) (Peters 2000). Reclaiming a dissemination model of communication alongside dialogue, Peters noted that not all culture is mutual or interactive. But he also insisted that 'the rehabilitation of dissemination is not intended as an apology for the commissars and bureaucrats who issue edicts without deliberation or consultation'.

In an observation with an obvious bearing on the assessment of dialogue and engagement activities in PCST, Peters noted that the adoption of more strongly audience-oriented communication styles and strategies chimed with the needs and precepts of marketing (that is, more effective persuasion of the public) and did not necessarily engender more active citizen participation:

Dialogue is valuable, but it is a strict and jealous god. It is not necessarily the most vernacular form of political talk, but Ihe most demanding and difficult; dialogue's law is not self-expressive pleasure but rather self-denying listening. Conversation is no more free of history, power, and control than any other form of communication. (Peters 2000)

Peters's critique of exaggerated claims made for conversation and dialogue is the source of a reconsideration of the 'infatuation with dialogue' in public relations. Stoker and Tusinski (2006) defend the possibility that dissemination can enhance responsibility, diversity and reconciliation and that dialogue may be based on a selective choice of stakeholders "who could reciprocate through an economic and emotional attachment 1 . They advocate engagement and reconciliation models as more authentic and more ethical than dialogue, because those models are more respectful of difference:

Using this framework, we engage people or publics in communication, not in an effort to change them or even to change us, but because as human beings, we value our relationships with other human beings.

It is perhaps surprising that a consideration of public relations practices could offer a basis for a critique of dialogue that implies no reversion to dissemination, much less the specific version of dissemination - the deficit model - that has prevailed in science communication. The specific terms used may not be entirely suitable, but an outline emerges of further options, in a space we shall call 'participation', where the aim is not in any supposedly measurable outcome but the process itself. 


\section{Complex Factors and Clear Choices}

In the 'co-evolution of science and society' (Gibbons 1999), the pressures and trends in relations between science and society are contradictory, or at least not one-directional.

This has implications for how the field of science communication models forms and reforms, and for how PCST practitioners and analysts see that field.

At the level of social theory, it has been argued influentially (Beck 1992) that individuals and groups are engaged in the continuous negotiation and assessment of risks, many of which derive from the impacts of scientific and technological developments. We are, on this basis, said to be in a 'risk society'. Full recognition of this would mean active engagement between scientists, technologists, policymakers, interest groups and others, to assess current trends in and future implications of developments in science and technology.

The notion of 'Mode 2' science (Gibbons et al. 1994) describes a practice of science that is open and reflexive, where boundaries between disciplines and between science and non-science are increasingly porous. This socially contextualized science is assessed not only on the basis of the reliability of the knowledge it produces (as in 'Mode 1' science) but also on its social robustness.

Whether such theories are taken as descriptions of current reality or as outlines of emerging trends, they find some support in the increasing public presence of scientists in a variety of advisory, consultative, expert witness, debating and other roles in which they present options and views arising from their professional experience and capacity, rather than packaged elements of proven knowledge (Peters 2008).

In dealing with such topics as embryonic stem-cell research, energy, climate change and pandemic risks, science comes into contact with ethics, economics, public service provision and business. In those contexts, knowledge derived from scientific research is just one ingredient of public policymaking and public debate, and scientists are called on to open science-in-themaking for public scrutiny.

One factor drawing scientists more often into the public domain as 'public experts' is the growth in number and influence of civil society groups or non-government organizations (NGOs) concerned with matters that have significant scientific content. It has often been claimed that environmentalism, as it developed from the 1960s, had a specific impact on public attitudes to science. In many countries, the rate at which various applications of biotechnology have been adopted has been significantly influenced by the strength and the stances of NGOs.

These developments have led some to advocate 'upstream engagement' of the public, in part through such organizations, in the shaping of the scientific research agenda (Wilsdon and Willis 2004). Civil society organizations receive express attention from national governments in European countries that have been early adopters of dialogue techniques such as consensus conferences. The European Commission supports initiatives to develop such techniques in association with NGOs.

Technological developments also facilitate this opening of science to public view. The pervasive use of internet communication for internal scientific and public communication creates opportunities for more interactivity between scientists and publics. It also permits public access to 'backstage' conversations between scientists, including those that negotiate uncertainties in science. In this way, the internet helps to turn science communication 'insideout' (Trench 2008). 
Against these trends that favour greater openness and reflexivity in science, and thus encourage approaches to science communication based on dialogue, engagement and participation, there are simultaneous trends working in different directions, or working to limit the impact of such approaches.

Oddly enough, the most powerful of these countervailing trends is the very widespread, almost universal, public policy commitment to the 'knowledge economy' or the 'knowledge society'. Over the past decade, this theme of policymaking has come to assume a central place for very many national governments and international intergovernmental bodies. A common feature of knowledge economy policies is the high priority they attach to science and technology or, more specifically (and tellingly), to research and development.

At one level, this development appears to be a boost for science communication: scientific research gets more attention and resources; new scientific institutions are established, through merging and redefinition of existing ones or from the ground up: outreach or dissemination is often required of those receiving public funds. However, the limits quickly become clear: the knowledge at issue in the knowledge society is almost exclusively knowledge that can be turned into technologies, services and products. The reflective, interpretive knowledge of the humanities and social sciences hardly features, and the prevailing models for performance measurement discriminate against them.

Even within the natural sciences, the policy view is limited and scientists wishing to secure a slice of the larger resources pie are obliged to fit their work into largely predetermined categories. The dominant discourses and policies of the knowledge society obscure science's cultural and social value, and science communication's possible contribution to broad social access, balanced dialogue and cultural completeness. 'Knowledge' economy/society policies and discourses may be promoting a new social separation of science, rather than fuller integration.

The common emphasis on improving national competitiveness within a global knowledge economy also constrains the practice of dissemination and outreach. Across the developed world - and, in different ways, in the developing countries - there is perceived to be a crisis in the interest of young people in science studies and careers. Projections of future shortfalls in the supply of scientifically and technically qualified people are a commonplace of knowledge economy strategies. Those driving the knowledge economy look to the institutions benefiting from the new funds to reverse this trend: public communication is seen to serve a labour market purpose. Working with school students, although it may take interactive forms (because no other form would engage these audiences), may be most importantly about addressing a public deficit in attitudes towards science, and thus a reinvention of the supposedly discarded deficit model of science communication.

In concert with this public policy trend, interest groups have emerged in and on the fringes of the scientific communities. They propose doctrinaire responses to perceived 'anti-science' tendencies in the public, or reject the proposition for equitable dialogue on the basis that it downgrades legitimate expertise. For example, Durodié (2003) argues against the trend to dialogue on the basis that it mistakenly posits that the validity of scientific knowledge can be democratically decided and that it potentially absolves policymakers from responsibility for their decisions. Durodié was vigorously contested by Jackson et al (2005), who not only defended the value of dialogue but extended its reach 'upstream', to deliberation on 'setting the research agenda'.

That discussion is a clear reminder that science communication does not come in a one-sizefits-all model, called 'dialogue'. And the terminology of 'dialogue' can refer to a wide range of 
practices and strategies. As indicated in the discussion of dialogue approaches to public relations, as also claimed by Wynne (2006) in relation to PCST dialogue and engagement initiatives in Britain, and as evidenced in the insistence of many in this field on 'real dialogue' and 'public engagement', the dialogue banner may be used to refer to refinement rather than replacement of a dissemination model. The talking-back part of 'two-way communication' in such situations may be, above all, a means to retime the talking-to; the listening may be more for improved targeting than for learning. In this way, there is no significant departure from linear, engineering-derived views of communication. The sender retains primary control; all that has been added is a feedback loop.

When Hanssen (2004) says that 'the exact meaning of scientific research can only be clarified on the basis of a dialogue with a broad range of social actors', he has something more farreaching in mind than a discussion between experts and lay groups on, say, the latest evidence of public risks from high-voltage power lines. Indeed, the analogy he draws with public interpretation of art, and the distinction he makes between discussion of application and discussion of implication, make this very clear. Either the notion of dialogue has to be stretched to breaking point or, as I shall suggest below, we use an additional concept to encompass such approaches.

The complex social circumstances I have sketched present a landscape very different from that suggested by discussions of a decisive shift from deficit to dialogue. They also challenge people in science communication to articulate much more clearly the strategic choices they are making.

When we consider the deficit-dialogue relationship carefully, we can see that there are circumstances in which the 'old' way can have a legitimate place, after it has been weighed up with due care. Hanssen (2004) speaks of the challenge of 'working on the integration of classical and alternative forms of science communication'. Dickson (2005) has made a defence of the deficit model, reflecting his own particular interest in science communication in developing countries.

In his assessment of the crossroads at which science communication found itself at the start of the millennium, Miller (2001) noted that the then British Minister for Science, Lord Sainsbury, had pronounced the demise of the deficit model but warned:

the end of the deficit model does not mean there is no knowledge deficit... many communications about science will still mainly be about passing on the latest scientific knowledge.

Sturgis and Allum (2005) note the many criticisms of the received deficit model, considering them 'in many ways valid', but they argue that the criticisms 'do not sufficiently problematize the deficit model to justify scrapping it altogether'. A report on Engaging Science, a 2006 conference in Britain, observed that 'in rejecting the knowledge deficit model so forcefully ... the narrow view of public engagement ignores the clear public appetite for information, as well as the empowering character of an understanding of the nature of science' (Wellcome Trust 2006).

Einsiedel (2007) claims that 'a more nuanced view of publics has emerged': they can be active and knowledgeable, playing multiple roles and receiving science but also shaping it. However, she also cautions against overstating how far the balance has shifted between scientists and publics. She cites Jasanoff (2005), who pointed out that not all members of the public want to be 'full-blooded cognitive agents who test and appraise public knowledge claims, including those of experts, according to culturally sanctioned criteria of competence, virtue and reasoning'. Einsiedel had earlier argued that the 'cognitive deficit model' and 'interactive science model' both: 
... have things to contribute to the ongoing discussions about the public and science ... Contrasting [the cognitive deficit model] with the interactive science model may have analytical value, but one thereby tends to overemphasize the stark differences between the two and to overlook the possibility that these frameworks may be complementary rather than mutually exclusive. (Einsiedel 2000)

To various degrees, these versions of a reclaimed deficit model remove from it the presumption of incorrigible cognitive deficiency in the public, and the assumption that more knowledge or information about science means greater appreciation or support for science.

From this brief discussion, we see that:

- The deficit model survives as the effective underpinning of much science communication.

- A legitimate case can be made for retention of a dissemination model in certain circumstances.

'Dialogue' refers to multiple options that span a considerable spectrum. The bipolar view of deficit and dialogue is neither an accurate account of recent developments nor a useful guide to current and future practice and analysis. There is at least as much continuity as discontinuity in the historical trend. There are several variations on dissemination, of which the deficit model is just one. There are variations on dialogue, among them consultation and engagement, where 'consultation' is taken to refer to dialogue set up on a relatively restricted agenda, for a specific purpose, and in a limited time frame, and 'engagement' involves a relatively open agenda, die content of which can change, in a process might not be strictly time-bound.

Van Sanden and Meijman (2008) draw a related distinction between dialogue with a functional goal and dialogue with a conceptual goal. The 'conceptual goal' appeared to be in the mind of Irish Deputy Premier Mary Harney in a speech that proposed a move 'towards a civic science', defined as a science engaged with and invited into the national dialogue ... responsive to the public and worthy of the public trust' (Harney 2003). (It is worth noting that the challenge of 'civic dialogue' that Ms Harney presented to her audience of scientists, other academics and policymakers was not taken up.)

The many possible approaches to PCST can be seen as on a continuum, in which the boundaries between neighbouring options are porous and shifting. The next section of this chapter proposes a framework for situating various models of science communication. It departs from the deficitdialogue dichotomy for all the reasons outlined above, but also in order to add a third main frame - participation - within which we can situate models and strategies that go beyond the limits of real and existing dialogue.

\section{Framework for Analysis}

Among recent contributions to the discussion of identifiable models of science communication are the following:

- A map of science communication activities prepared for the Wellcome Trust in Britain identified three models of communication in relations between science and the media: the deficit model, the consultation model and the engagement model (Research International 2000).

- In a review of scientists' discussions of public communication, a colleague and I (Trench and Junker 2001) identified five models of communication that scientists implicitly considered available to them in their public interventions: deficit, dissemination, duty, dialogue and deference. 
- Lewenstein (2005) described four models: the deficit model, the contextual model, the lay expertise model and the public participation model.

The precise number is not significant in itself. What matters in an endeavour of this kind is that the entities named are (at least approximately) conceptually equivalent to each other and that the distinctions between them are reasonably clearly drawn. For example, the contextual model may be taken as contained within the dialogue model, as implied by Gross (1994):

The contextual model implies an active public: it requires a rhetoric of reconstruction in which public understanding is the joint creation of scientific and local knowledge ... In this model, communication is not solely cognitive; ethical and political concerns are always relevant.

Table 1 shows a grid centred on a triad of models of science communication that distinguishes between dialogue and participation on the basis of my earlier discussion of the ambiguities and limits of dialogue in many of its current applications. The three models are:

- Deficit. Science is transmitted by experts to audiences perceived to be deficient in awareness and understanding.

- Dialogue. Science is communicated between scientists and their representatives and other groups, sometimes to find out how science could be more effectively disseminated, sometimes for consultation on specific applications.

- Participation. Communication about science takes place between diverse groups on the basis that all can contribute, and that all have a stake in the outcome of the deliberations and discussions.

$\underline{\text { Table 1: Analytical Framework of Science Communication Models }}$

\begin{tabular}{|c|c|c|c|c|}
\hline $\begin{array}{l}\text { Base } \\
\text { communication } \\
\text { models }\end{array}$ & $\begin{array}{l}\text { Ideological and } \\
\text { philosophical } \\
\text { associations }\end{array}$ & $\begin{array}{l}\text { Dominant } \\
\text { models in } \\
\text { PCST }\end{array}$ & $\begin{array}{l}\text { Variants on } \\
\text { dominant } \\
\text { PCST models }\end{array}$ & Science's orientation to public \\
\hline Dissemination & $\begin{array}{l}\text { Scientism } \\
\text { Technocracy }\end{array}$ & Deficit & $\begin{array}{l}\text { Defence } \\
\text { Marketing }\end{array}$ & $\begin{array}{l}\text { They are hostile } \\
\text { They are ignorant } \\
\text { They can be persuaded }\end{array}$ \\
\hline Dialogue & $\begin{array}{l}\text { Pragmatism } \\
\text { Constructivism }\end{array}$ & Dialogue & $\begin{array}{l}\text { Context } \\
\text { Consultation } \\
\text { Engagement }\end{array}$ & $\begin{array}{l}\text { We see their diverse needs } \\
\text { We find out their views } \\
\text { They talk back } \\
\text { They take on the issue }\end{array}$ \\
\hline Conversation & $\begin{array}{l}\text { Participatory } \\
\text { democracy } \\
\text { Relativism }\end{array}$ & Participation & $\begin{array}{l}\text { Deliberation } \\
\text { Critique }\end{array}$ & $\begin{array}{l}\text { They and we shape the issue } \\
\text { They and we set the agenda } \\
\text { They and we negotiate meanings }\end{array}$ \\
\hline
\end{tabular}


We might say that these represent one-way, two-way and three-way models. The first two are essentially linear, and (he last is multidirectional: communication takes place back and forth between experts and publics and between publics and publics. Whereas the main object of dialogue may be the applications of science, in the participation model the concern is more with implications. However, as in any analytical scheme, the boundaries between categories will appear more definite than they manifest themselves in actual application.

By characterizing the dominant models in science communication in this way, I am not proposing a hierarchy or an evolution. All three will continue to have their uses in particular circumstances. In an extended communication project or in an unfolding public debate, participants may move from one approach to another. However, as a general observation, we might say that communication processes become more open-ended and more open to values as well as facts in the transition from deficit to dialogue and participation.

In Table 1, the three models are presented in column 3 with 'upstream' and 'downstream' associations ranged to left and right, respectively. The horizontal alignment of models and their corresponding public orientations is intended to indicate the relative emphasis on the scienceor public-centredness of the process.

In column 1, the dominant science communication models are related to established and more widely recognized communication models, as discussed above. Column 2 lists some ideological and philosophical perspectives that affect how the models arc applied in the particular contexts of PCST. These need more discussion than space permits here. The influence among scientific communities of scientism (the belief that science is the superior knowledge system and can provide answers to all the questions worth asking) may well be the key factor in the shaping of dissemination as a deficit model. Wynne (2006) maintains that scientism is the ideological underpinning of the common characterization of certain public dispositions as 'anti-science'.

Column 4 lists some known variants of the three core models of science communication. Introducing these variants allows us to consider more options, but also to recognize smaller gradations when analysing current practices. It also offers a wider repertoire for planning science communication initiatives:

Defence. ${ }^{\mathrm{v}}$ Here the public is envisaged as hostile; one example is the posture of the Richard Dawkins Foundation (see above), but the model can also be recognized in communication that focuses in other ways on 'anti-science'.

Marketing. Here the purpose is 10 persuade the public, for example about the drop in science and technology student numbers, perhaps by promoting successful scientists as role models or presenting science as 'fun'.

Context. Contextualized practices take into account the diversity of publics and of the ways their experiences and perceptions shape their reception of information. These practices can be functionalist, as in marketers' 'segmentation' of markets, or more culturally situated, as in the consideration of PCST in multicultural societies.

Consultation. The public's opinions are sought by various means, with a view to redefining messages or negotiating about applications.

Engagement. Here there is a stronger emphasis on how publics express concerns, raise questions and become actively involved.

Deliberation. This is presented as a 'heightened' form of public participation, which calls on a wider set of understandings about democratic processes, and in which the public contributions about the 'why' and 'why not' of science help set the agenda for science communication and, eventually, for science. 
Critique. Here science is held to account through reference to other intellectual disciplines and cultural activities that can offer insights into the public meanings of science. The term 'critique' is used by analogy with the public processing of experiences and interpretations of the arts and other cultural expression.

In column 5, dominant models and the variants are translated into terms of an implicit modelling, within scientific communities, of the publics' role. This translation draws on discussion among science communicators and in this chapter.

To articulate choices more clearly, as I have advocated, it would be worthwhile to develop an alternative model or models - looking at these processes from the perspective of attentive and active publics.

\section{References}

Beck, U. (1992). Risk society_-Towards a new modernity. London: Sage.

Brecht, B. (1979/80). Radio as a means of communication - A talk on the function of radio. Screen, 20(3-4), 24-28.

Bums, T. W., O’Connor, D. J. \& Stocklmayer, S. M. (2003). Science communication: A contemporary definition. Public Understanding of Science, 12(2), 183-202.

Cartlidge, E. (2007). New formula for science education. Physics Today, January. 10-11.

Dawkins, R. (2006). The god delusion. London: Bantam Press.

Dickson, D. (2005). The case for a deficit model of science communication. Paper presented to PCST Working Symposium, Beijing, June 2005.

Dixon, B. (2007). What do we need to say to each other? New Scientist, 6 January, 46-47.

Durodié, B. (2003). Limitations of public dialogue in science and the rise of the new 'experts'. Critical Review of International Social and Political Philosophy, 6(4), 82-92.

Einsiedel, E. (2000). Understanding 'publics' in public understanding of science. In M. Dierkes \& C. von Grote (Eds.). Between understanding and trust-The public, science and technology. London, New York: Routledge. 205-215.

Einsiedel, E. (2007). Editorial: Of publics and science. Public Understanding of Science, 16(1). 5-6.

Gibbons, M. (1999). Science's new social contract with society. Nature, 402 (2 December) C81-84.

Gibbons, M., Limoges, C, Nowotny, H., Schwartzman, S., Scott, P. \& Trow, M. (1994). The new production of knowledge-The dynamics of science and research in contemporary societies. London, Thousand Oaks, California, New Delhi: Sage.

Giddens, A. (1994). Beyond left and right—The future of radical politics. Cambridge: Polity Press.

Gross, A. (1994). The roles of rhetoric in the public understanding of science. Public Understanding of Science, 3(1), 3-23.

Grunig, J. \& Hunt. T. (1984). Managing public relations. New York: Holt, Rinehart and Winston.

Hanssen, L. (2004). The representation of science, in Public communication on science and technology-Some insights from the Netherlands. Amsterdam: National Organisation for Public Science Communication.

Harney. M. (2003). Towards a civil science-A mission for the 21st century: An address to the Royal Irish Academy. Dublin: Royal Irish Academy.

Jackson, R., Barbagallo, F. \& Hasic, II. (2005). Strengths of public dialogue on science-related issues. Critical Review of International Social and Political Philosophy, 8(3), 349-358. 
Jasanoff, S. (2005). Designs on nature: Science and democracy in Europe and the United States. Princeton, New Jersey: Princeton University Press.

Lee, R. G. and Garvin, T. (2003). Moving from information transfer to information exchange in health and health care. Social Science and Medicine, 56,449-464.

Lewenstein, B. (2005). Models of public communication of science and technology. Manuscript retrieved on 25 November 2007 from http://communityrisks.cornell.edu/BackgroundMaterials/Lewenstein2003.pdf.

McQuail, D. (1997). Audience analysis. London: Sage.

Miller, S. (2001). Public understanding of science at the crossroads. Public Understanding of Science, 10(1), 115-120.

Peters, H. P. (2008). Scientists as public experts. In M. Bucchi \& B. Trench (Eds.), Handbook of public communication of science and technology. London: Routledge.

Peters, J. D. (2000). Speaking into the air-A history of the idea of communication. Chicago, London: University of Chicago Press.

Research International (2000). Science and the public: Mapping science communication activities. London: Wellcome Trust. Retrieved on 18 November 2007 from http://www.wellcomc.ac.uk/asscis/wtd003418.pdf.

Richard Dawkins Foundation for Reason and Science (2007). Mission statement. Retrieved on 18 November 2007 from http://www.richarddawkinsfoundation.org.

Rosen, J. (1999). What are journalists for? New Haven, London: Yale University Press. Sandman, P. (1987). Risk communication: Facing public outrage. EPA Journal, 13(9), 21-22. Retrieved on 18 November 2007 from http://www.psandman.com/articles/facing.htm.

SCST (Select Committee on Science and Technology) (2000). Science and society. Third report. London: House of Lords. Retrieved on 19 November 2007 from http://www.publications.parliament.uk/pa/ld199900/ldselccl/ldsctech/38/3801.htm.

Stoker, K. \& Tusinki, K. (2006). Reconsidering public relations' infatuation with dialogue: Why engagement and reconciliation can be more ethical than symmetry and reciprocity. Journal of Mass Media Ethics, 21(2/3), 156-176.

Sturgis, P. \& Allum, N. (2005). Science in society: Re-evaluating the deficit model of public attitudes. Public Understanding of Science, 13(1), 55-74.

Technology Foresight Ireland (1999). Health and life sciences-Report from the Health and Life Sciences Panel. Dublin: Irish Council for Science, Technology and Innovation, and Forfas.

Trench, B. (2007). Science communication and citizen science-How dead is the deficit model? Paper presented to Scientific Culture and Global Citizenship, 9th International Conference on PCST, Seoul, Korea, 17-19 May 2006.

Trench, B. (2008). Internet: Turning science communication inside-out? In M. Bucchi \& B. Trench (Eds.), Handbook of public communication of science and technology. London, New York: Routledge.

Trench, B. \& Junker, K. (2001). How scientists view their public communication. Paper presented to Trends in Science Communication Today, 6th International Conference on PCST, Geneva, Switzerland, January 2001. Retrieved on 25 November 2007 from http://visits.web.cern.ch/visits/pcst2001/proc/Trench-Junker.doc.

Van Sanden, M. \& Meijman, F. (2008). Dialogue guides awareness and understanding of science-An essay on different goals of dialogue leading to different science communication approaches. Public Understanding of Science, 17(1), 89-103

Wellcome Trust (2006). Meeting of minds-Engaging debate at the Engaging Science conference. Wellcome News, 47 (June 2006), 12-13. 
Wilsdon, J. \& Willis, R. (2004). See-through science: Why public engagement needs to move upstream. London: Demos.

Wilsdon, J., Wynne, B. \& Stilgoe, J. (2005). The public value of science - or how to ensure that science really matters. London: Demos.

Wynne B. (1991). Knowledges in context. Science, Technology and Human Values, 16(1), 111-121.

Wynne, B. (2006). Public engagement as n means of restoring public trust in science-Hitting the notes but missing the music? Community Genetics, 9(3), 211-220.

Ziman, J. (1991). Public understanding of science. Science, Technology and Human Values, 16(1), 99-105.

\footnotetext{
${ }^{\mathrm{i}}$ http://wwww.bbsrc.ac.uk

ii richarddawkins.net and richarddawkinsfoundation.org

iii Statement published at http://www.irishskeptics.net

${ }^{\text {iv }} \mathrm{http}: / /$ www.senseaboutscience.org
}

${ }^{v}$ Colin Johnson, vice-president of the British Association (BA), offered this variant on the deficit model in response to a presentation I gave to the BA Festival of Science in Dublin during September 2005. 